\title{
Prior feeding practices do not influence locoweed consumption
}

\author{
M.H. RALPHS, G. GREATHOUSE, A.P. KNIGHT, D. DOHERTY, J.D.GRAHAM, B.L. STEGELMEIER, AND L.F. \\ JAMES
}

Authors are Rangeland Scientist, USDA/ARS Poisonous Plant Lab, Logan Ut 84341; Ranch Manager, CSU Research Foundation; Dept. Head, Clinical Sciences Dept.; former graduate student, Animal Science Dept., Colorado State Univ., Ft. Collins Colo 80523;County Agent, Union County Extension, Clayton NM. 88415; Pathologist, and Research Leader, USDA/ARS Poisonous Plant Lab.

\begin{abstract}
Anecdotal evidence suggests that cattle fed alfalfa hay during the winter are inclined to graze locoweed on spring range. Two studies were conducted to compare the influence of feeding alfalfa hay vs grass hay during the winter on subsequent consumption of white locoweed (Oxytropis sericea Nutt. ex T\&G) in the spring. Eight cows were daily fed alfalfa hay $(15.2 \% \mathrm{CP}$ in $1998,17.1 \%$ $\mathrm{CP}$ in 2000) and 8 cows were daily fed grass hay $(10.7 \% \mathrm{CP}$ in $1998,12.1 \% \mathrm{CP}$ in 2000 ) plus $20 \%$ protein molasses block during the January-April winter feeding period. Treatment groups grazed in separate pastures $(8 \mathrm{ha})$ on white locoweed-infested range in May and June in northern Colorado in 1998 and in northeast New Mexico in 2000 . Diets were estimated by bite count. There was no difference in locoweed consumption between the 2 groups $(P>0.22)$. Cattle grazed locoweed for $5 \%$ of diets in Colorado and $10 \%$ of diets in New Mexico. Feeding alfalfa hay over winter did not predispose cattle to graze locoweed in the spring. Previous research showed other feeding practices or supplements do not affect locoweed consumption or poisoning. Prevention of locoweed poisoning requires denying access to locoweed when it is relatively more palatable than associated forages.
\end{abstract}

Key Words: Oxytropis sericea, alfalfa hay, grass hay, cattle, poisonous plant

Locoweeds (Astragalus and Oxytropis spp.) are the most destructive group of poisonous plants on western rangelands (Kingsbury 1964). Species of Astragalus and Oxytropis contain the toxic alkaloid swainsonine (Molyneux and James 1982) which inhibits essential enzymes in glycoprotein processing, resulting in buildup of unmetabolized hybrid glycoproteins and disruption of hormone and enzyme synthesis, transport and receptors (see Stegelmeier et al. 1999 for review). Outward effects on animals include reduced fertility of both males and females, abortions, neurological disturbances (ranging from extremes of depression to aggression), and impaired prehension of food and water, resulting in weight loss and eventual starvation (James et al. 1981).

Locoweed causes such an insidious poisoning that ranchers and researchers have attempted many practices to reduce the inci-

Authors wish to thank Jennifer Vaad and Becky Floyd for assistance in data collection, Joel Vaad in handling the animals, and Jane Chambers in running swainsonine analysis.

Manuscript accapted 1 Oct. 01.

\section{Resumen}

Evidencia anecdótica sugiere que el ganado bovino alimentado con heno de alfalfa durante el invierno tiende a consumir "locoweed" en pasturas naturales durante la primavera. Se condujeron dos estudios para comparar la influencia de ofrecer heno de alfalfa versus heno de gramineas durante el invierno sobre el posterior consumo de "locoweed" blanco (Oxytropis sericea Nutt. Ex T\&G) durante la primavera. Ocho vacas fueron alimentadas diariamente con heno de alfalfa (15.2\% PC en 1998, 17.1\% PC en 2000) y 8 vacas fueron alimentadas diariamente con heno de gramineas $(10.7 \%$ PC en $1998,12.1 \%$ en 2000) mas $20 \%$ de un bloque de proteina y melazas durante el periodo de alimentación de invierno que fue de Enero hasta Abril. Los grupos pastorearon en areas separadas (8 ha) en una pastura natural infestada con "locoweed" blanco en el norte de Colorado durante Mayo y Junio de 1998 y en el noreste de Nuevo Mexico en 2000. Las dietas fueron estimadas por el método de contar bocados. No existio diferencia en el consumo de "locoweed" entre los 2 grupos $(P>0.22)$. Los bovinos pastorearon "locoweed" por un $5 \%$ de sus dietas en Colorado y por un $10 \%$ de sus dietas en Nuevo Mexico. La oferta de heno de alfalfa durante el invierno no predispuso al ganado para pastorear "locoweed" durante la primavera. Investigación previa muestra que otras practicas de alimentación o suplementos no afectan el consumo de "locoweed" o la posibilidad de intoxicación con esta planta. La prevención de la intoxicación con "locoweed" requiere negar el acceso al "locoweed" cuando este es relativamente mas palatable que los forrajes asociados.

dence of poisoning. One practice that was thought to influence locoweed consumption was prior feeding of alfalfa during the winter. The objective of this study was to test the hypothesis that cattle fed alfalfa hay over the winter will graze more white locoweed (Oxytropis sericea Nutt. ex T\&G) on spring range than cattle wintered on grass hay.

\section{Methods}

\section{Winter feeding regimen}

Sixteen, 2-year-old first-calf heifers naive to alfalfa hay and white locoweed were randomly assigned to 2 treatment groups in winter 1998 at the Colorado State University Research Foundation Maxwell Ranch, $25 \mathrm{~km}$ north of Ft. Collins, Colo. $\left(40^{\circ} 56.39^{\prime} \mathrm{N}, 105^{\circ} 15.33^{\prime} \mathrm{W}\right)$. Animals were handled by methods 
approved by an Institutional Animal and Care Use Committee. One group was fed native meadow grass hay $(10.7 \% \mathrm{CP}$, as fed) and supplemented with $20 \%$ proteinmolasses block $\left(0.9 \mathrm{~kg} \mathrm{cow}^{-1}\right.$ day $\left.^{-1}\right)$. The other group was fed alfalfa hay $(15.2 \%$ $\mathrm{CP}$, as fed). Cattle had free-choice access to hay fed in round bales in feeders. Hay was fed from 11 February to 15 May 1998 , and all cows calved during this period. Average weight at the beginning of feeding was $375 \mathrm{~kg}$. Cows in the grass group lost $57 \mathrm{~kg}$, and those in the alfalfa group lost $32 \mathrm{~kg}$ during the feeding/calving period. Mean body condition score (scale 1-9) at the beginning of the grazing trial was 3.9 , and 4.1 for the grass and alfalfa-fed groups, respectively.

The cows were used on another locoweed grazing trial in 1999 (Ralphs et al. 2001), but were separated into their original groups and fed their respective rations (alfalfa vs grass hay) from 13 December 1999 to 16 May 2000 at the USDA/ARS Poisonous Plant Research facility at Logan, Ut. The cows were group-fed about $11 \mathrm{~kg} \mathrm{cow}^{-1} \mathrm{day}^{-1}$ of the respective hays from large rectangular bales. The orchard grass hay contained $12.1 \% \mathrm{CP}$ (as fed) and alfalfa hay contained $17.1 \% \mathrm{CP}$ (as fed). The cows weighed $536 \mathrm{~kg}$ at the beginning of the feeding period. The grass-fed group lost $53 \mathrm{~kg}$ while the alfalfa-fed group gained $63 \mathrm{~kg}$ and the condition scores were about 4 and 6 respectively. The cows were bred to calve in July and were in the late stage of gestation during the spring grazing period. Only 5 cows from each group were available for the 2000 grazing trial because of early calving and illness. There was little locoweed available at the Maxwell Ranch in Colorado because of severe drought, therefore the cattle were trucked to a site $10 \mathrm{~km}$ southwest of Capulin, N.M. $\left(30^{\circ} 41.25^{\prime} \mathrm{N}, 104^{\circ} 08.35^{\prime}\right.$ W) where white locoweed was abundant for the spring grazing trial.

\section{Spring locoweed grazing trials}

The 1998 grazing trial on the Maxwell Ranch in Colorado ran from 15 May to 18 June. The cows were fasted overnight, weighed, then turned onto locoweedinfested pasture. The range site was a mixed-grass prairie on shallow gravely sandy loam soil derived from weathered granite. Dominant cool-season grasses on the uplands included Needle-and-thread (Stipa comata Trin. \& Rupr.), prairie junegrass (Koleria macrantha (Ledeb) Schultes), and squirrel tail (Elymus elymoides (Raf.) Swezey), with western wheatgrass (E. smithii (Rybe.) Gould) dominating the swales. Warm-season grasses were minor components: blue grama (Bouteloua gracilis (H.B.K.) Lag. ex Steudel), purple 3-awn (Aristida purpurea Nutt), and ring muhly (Muhlenbergia torreyi (Kunth) Hitchc. Ex Bush). White locoweed was the dominant forb, with fringed sagewort (Artemisia frigida Willd), Utah milkvetch (Astragalus utahensis (Torr.)T.\&.G), rose pussytoes (Antennaria microphylla Rydb), geranium (Geranium richardsonii Fisch. \& Trautv.), and Penstemon spp. present.

Standing crop was estimated at the beginning and end of both trials by clipping the forage classes (cool-season grass, warm-season grass, forbs, and locoweed) in 1 by $.25 \mathrm{~m}$ quadrats placed systematically at 20 step intervals along 2 transects in each pasture (40 plots total). Standing crop of forage classes was compared between pastures and beginning and end of each study separately using analysis of variance.

Two, 8 ha pastures were fenced with temporary electric fence. The 2 groups were randomly assigned to a pasture and were rotated to the other pasture every week to reduce pasture bias. The cows were brought into an onsite corral at the end of each week and blood samples were taken by jugular venipuncture. Serum was separated, frozen and later analyzed for swainsonine (Stegelmeier et al. 1995) as a measure of intoxication.

Cattle diets were estimated using a bite count technique. Each cow was observed for 5- minute periods and the number of bites of forage classes were counted: coolseason grass, warm-season grass, forbs, and locoweed. The cows were observed during the early morning and evening grazing periods, and each cow was observed at least once during each period. Observations were made each day during the 5 week grazing trial.

The 2000 grazing trial was conducted near Capulin, N.M. and ran from 18 May to 13 June. The site was a short-grass prairie on a silty clay loam soil. Blue grama was the dominant warm-season

Table 1. Standing crop of forages classes $(\mathrm{kg} / \mathrm{ha} \pm \mathrm{SE})$ at the beginning and end of grazing trials in 1998 and 2000.

\begin{tabular}{|c|c|c|c|c|c|c|}
\hline Year & Time & $\begin{array}{c}\text { Cool-season } \\
\text { grass }\end{array}$ & $\begin{array}{c}\text { Warm-season } \\
\text { grass }\end{array}$ & Forb & Locoweed & Total \\
\hline 1998 & $\begin{array}{l}\text { Begin } \\
\text { End }\end{array}$ & $\begin{array}{l}422 \pm 86^{*} \\
202 \pm 47^{*}\end{array}$ & $\begin{array}{l}209 \pm 29 \\
209 \pm 32\end{array}$ & $\begin{array}{r}63 \pm 11 * * \\
63 \text { (kg/ha)--- } \\
156 \pm 26^{* *}\end{array}$ & $\begin{array}{r}121 \pm 27^{\mathrm{t}} \\
66 \pm 21^{\mathrm{t}}\end{array}$ & $\begin{array}{l}811 \pm 56 \\
633 \pm 57\end{array}$ \\
\hline 2000 & $\begin{array}{l}\text { Begin } \\
\text { End }\end{array}$ & $\begin{array}{l}356 \pm 59^{* *} \\
101 \pm 18^{* *}\end{array}$ & $\begin{array}{l}362 \pm 37^{* *} \\
576 \pm 45^{* *}\end{array}$ & $\begin{array}{r}139 \pm 31 \\
98 \pm 17\end{array}$ & $\begin{array}{l}553 \pm 107 \\
501 \pm 99\end{array}$ & $\begin{array}{l}1466 \pm 201 \\
1283 \pm 139\end{array}$ \\
\hline
\end{tabular}

Difference in standing crop of forage classes at the beginning and end of each study:

$* * \mathrm{P}<0.01, * \mathrm{P}<0.05, \mathrm{t} \mathrm{P}<0.10$. grass, and cool-season grasses consisted of patches of western wheatgrass and occasional plants of squirreltail. White locoweed was the dominant forb, with fringed sage, and 3 non-toxic Astragalus species inhabiting the site. The area was fenced into two, 8-ha pastures using temporary electric fence. The groups were randomly allocated to pastures, and rotated to the other pasture on a weekly basis to minimize pasture bias. Diets were estimated by bite counts as described above.

Data from the 2 trials were analyzed separately because location and year were totally confounded. Percentage of bites of forage classes were compared between the two groups in a repeated measures mixed model using compound symmetry covariate structure (SAS Inst. Inc., Cary, N.C). Cow-within-group was the experimental unit, group was the main factor and week was the repeated factor.

\section{Results}

White locoweed comprised $15 \%$ of the standing crop in the Colorado grazing trial in 1998 , and $38 \%$ in the New Mexico trial in 2000 (Table 1). The greater abundance of locoweed may have contributed to the higher consumption of locoweed at New Mexico compared to Colorado (Table 2). There was no difference in abundance of locoweed between pastures in either trial $(P>0.10)$. Locoweed was in the late vegetative stage at the beginning of the Colorado trial, and matured to the late flower stage at the end of the trial. Locoweed was more advanced in the 2000 trial in New Mexico, which began in the flower stage, but the flowers aborted and few pods were produced due to drought. Crude protein content of locoweed was $15 \%$ in 1998 and $12.6 \%$ in 2000 . Cool season grasses such as needle-and-thread, prairie junegrass and squirrel tail were abundant on the Colorado site in 1998 and dominated the standing crop. Blue grama, a warm season grass, dominated the site of the 2000 study at New Mexico and began its seasonal growth during during the trial. 
Table 2. Composition of cattle diets estimated by a bite count technique $( \pm \mathrm{SE})$.

\begin{tabular}{llcccr}
\hline \hline Year & Group & Cool-season grass & Warm-season grass & Forb & Locoweed \\
\hline \multirow{2}{*}{1998} & Alfalfa & ---------1.3 & $8 \pm 0.8$ & $6 \pm 0.5$ & $5 \pm 0.8$ \\
& Grass & $-80 \pm 1.2$ & $8 \pm 0.9$ & $7 \pm 0.6$ & $4 \pm 0.5$ \\
2000 & Alfalfa & $36 \pm 1.5$ & $36 \pm 1.4$ & $19 \pm 0.9$ & $8 \pm 1.0$ \\
& Grass & $37 \pm 1.6$ & $30 \pm 1.3$ & $20 \pm 1.0$ & $13 \pm 1.4$ \\
\hline
\end{tabular}

There was no difference between groups in any of the forage classes in either year $(P>0.05)$.

The cool season grasses, western wheatgrass and squirreltail, were heavily grazed during the 2000 trial. There were no differences in standing crop of forage classes between pastures within the 2 grazing trials $(\mathrm{P}>0.05)$.

There was no difference in locoweed consumption between treatment groups in either year $(P>0.22)$. Mean locoweed consumption in the 1998 trial was $5 \%$ and $4 \%$ of bites for the alfalfa and grass hay groups, respectively; and $8.2 \%$ and $13.4 \%$, respectively in the 2000 trial (Table 2). However, there was a group by week interaction in the 1998 trial $(\mathrm{P}=$ $0.0001)$. The grass group started eating locoweed before the alfalfa group during the second week of the trial ( $9 \%$ of bites), but the alfalfa group consumed more locoweed $(21 \%$ of bites) during the 3 rd week (Fig. 1). Locoweed consumption declined during the last 2 weeks of the 1998 trial as locoweed matured and its availability declined.

Cattle began consuming locoweed at the beginning of the 2000 trial (10-20\% of bites, Fig. 1). Locoweed consumption declined in week 3 , but then increased during the last 2 days of the trial. In previous locoweed grazing trials on short-grass prairies in northeastern New Mexico (Ralphs et al. 1993, 1997a, 1997b), cattle reduced locoweed consumption in late May and early June and ceased grazing it as it matured into the pod stage and warm-season grasses began rapid growth. In another study at the Colorado site, cattle ceased grazing white locoweed as it matured into the mature pod stage in July 1998, but continued to consume its leaves throughout the summer in 1999 (Ralphs et al. 2001). Summer rains were above average in 1999 in Colorado and the leaves of white locoweed remained green and succulent.

Cool-season grasses were abundant and dominated cattle diets in 1998 at Colorado (Table 2). Warm season grasses were the dominant forage class at New Mexico, and diets were evenly split between cool-season grass that had matured, and warm-season grasses that were beginning to grow rapidly. Cattle preferred and sought-out the low growing, nontoxic Astragalus species and other forbs in the 2000 trial (Table 2).

There was a moderate correlation between swainsonine in the blood and locoweed consumption $(r=0.79)$ in the 1998 trial. When the groups were compared separately, the alfalfa group had a stronger correlation $(\mathrm{r}=0.82)$ compared to the grass group $(r=0.67)$. Swainsonine in the blood followed locoweed consumption of the alfalfa group very closely (Fig. 2). Swainsonine in the grass group dropped in week 3 to a greater extent than the bite counts indicate. Swainsonine is cleared rapidly from the blood (Stegelmeier et al. 1995). Therefore, the drop in swainsonine was due to a decline in locoweed consumption during the latter part of that week, whereas the higher consumption of locoweed at the beginning of the week kept the weekly average consumption elevated.

There were no clinical signs of poisoning during either study. Cattle must graze locoweed for 10 to $25 \%$ of their diets for 3-4 weeks before signs of poisoning are apparent. The high levels of locoweed consumption and swainsonine in the blood
1998 study
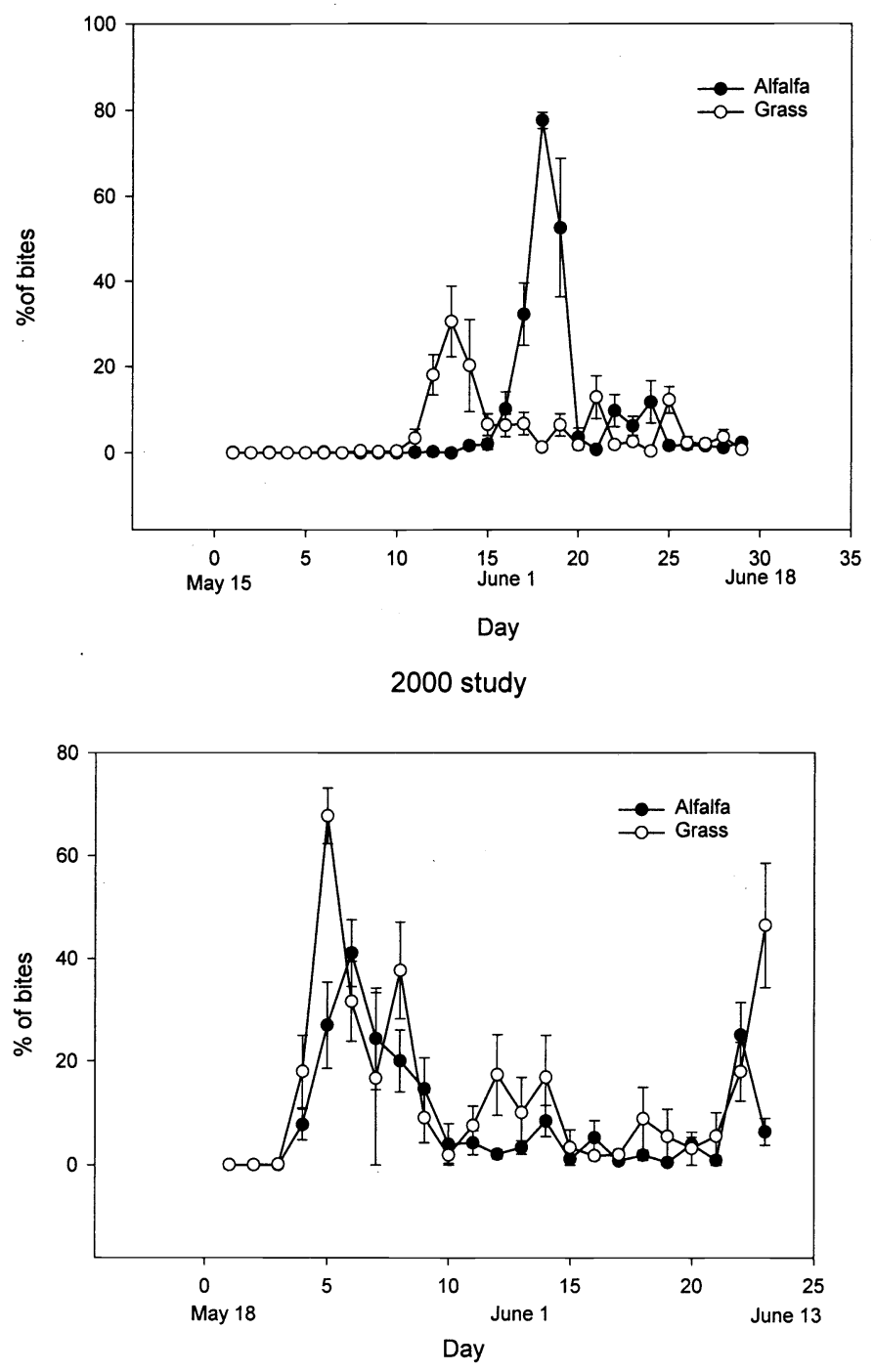

Fig. 1. Daily consumption of locoweed by cattle in the alfalfa and grass - fed groups in the 1998 and 2000 grazing trials (alfalfa group obscured by open circles during first 10 days of the 1998 trial). 


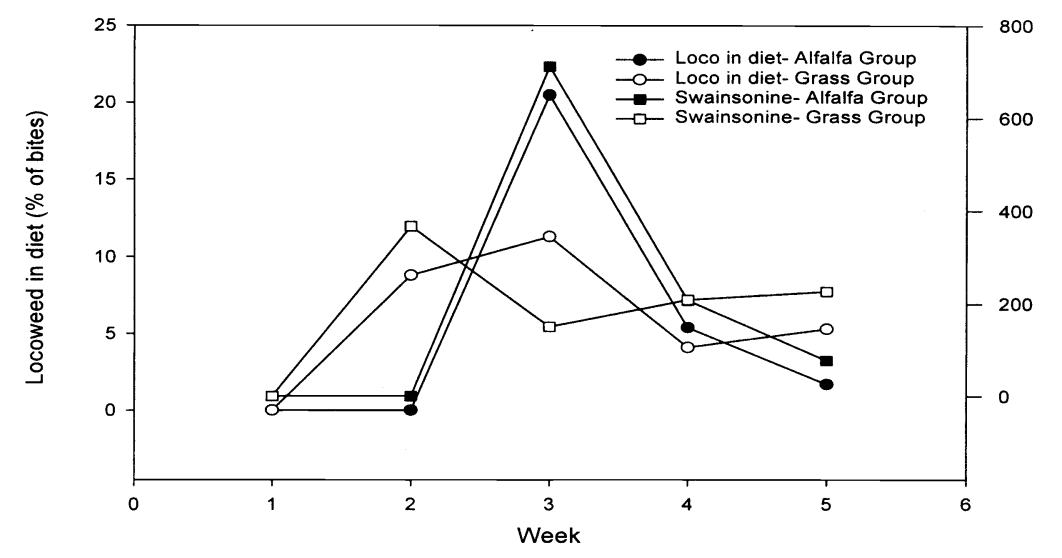

Fig. 2. Relationship between locoweed consumed (as estimated by bite counts) and swainsonine level in the blood in the 1998 grazing trail.

during these trials were not sustained for sufficient time to poison these animals.

\section{Discussion}

Cattle fed alfalfa hay during the winter did not consume more locoweed in the spring and early summer than cattle fed grass hay. Despite differences in nutritional plane or body condition, there was no difference in subsequent locoweed consumption. The notion that alfalfa (a highly nutritious legume) predisposes cattle to graze locoweed (also a highly nutritious legume) was unsubstantiated in this study. Other anecdotal evidence suggested that cattle wintered on green winter wheat are prone to graze locoweed when turned onto shortgrass prairie in the spring, based on the assumption that cattle accustomed to eating green forage would continue to seek out green-growing locoweed. A previous grazing trial showed there was no difference in locoweed consumption between cows wintered on wheat pasture or native range (Ralphs et al. 1997b).

Many minerals and feed additives have been investigated looking for "silver bullets" to prevent poisoning. Mineral supplements did not prevent poisoning, nor delay symptoms in sheep fed Garboncillo (Astragalus wootonii Sheld) (James and VanKampen 1974), or prevent cattle from grazing white locoweed (Allison and Graham 1999). Clay minerals have some scientific theory for their use since their differing electrical charges may bind to swainsonine, but a variety of clays and minerals were not effective in preventing or reducing locoweed poisoning (Bachman et al. 1992, Pulsipher et al. 1994). Neither did vitamin E/selenium injections hasten recovery from locoweed poisoning
(Richards et al. 1999). This is not to say that mineral supplements should not be used. Where minerals are deficient in forage, supplements should be used to maintain animal health, but they are unlikely to prevent locoweed poisoning.

There was also concern that implants which stimulate growth may enhance locoweed poisoning. Implants increase intake and rate of gain, thus animals may graze less selectively and/or consume more locoweed. On the other hand, estrogen from implants may provide some neurological protection. An estradiol implant did not cause steers to select more locoweed in a grazing trial, and did not affect the degree of poisoning or rate of recovery in a locoweed feeding trial (Mikus et al. 2001).

\section{Management Implications}

Cattle fed alfalfa during the winter did not consume more locoweed in the spring and early summer than cattle fed grass hay. Previous research indicated that other preconditioning feeding practices or supplements have not prevented cattle from grazing locoweed. Prevention of locoweed poisoning at this point in time lies in not allowing animals to graze locoweedinfested areas when it is relatively more palatable than associated forages.

\section{Literature Cited}

Allison, C. and J.D. Graham. 1999. Reducing locoism with management decisions. pp. 64-66 In: T.M. Sterling and D.C. Thompson (eds), Locoweed Research Updates and Highlights, New Mexico Agr. Exp. Sta. Res. Rep. 730. Las Cruces, N.M.
Bachman, S.E., M.L. Galyean, G.S. Smith, D.M. Hallford, and J.D. Graham. 1992. Early aspects of locoweed toxicosis and evaluation of a mineral supplement or clinoptilolite as dietary treatments. J. Anim. Sci. 70:3125-3132.

James, L.F. and K.R. VanKampen. 1974. Effect of protein and mineral supplementation on potential locoweed poisoning in sheep. J. Amer Vet. Med. Assoc. 164:1043-1043.

James, L.F., W.J. Hartley, and K.R. VanKampen. 1981. Syndromes of Astragalus poisoning in livestock. J. Amer. Vet. Med. Assoc. 178:146-150.

Kingsbury, J.M. 1964. Poisonous Plants of the United States and Canada. Prentice-Hall, Entlewood Cliffs, N.J.

Mikus, J.H., G.C. Duff, C.R. Krehbiel, D.M. Hallford, D.A. Walker, J.D. Graham, and M.H. Ralphs. 2001. Effects of an estradiol implant on locoweed consumption, toxicity, and recovery in growing beef steers. Prof. Anim. Sci.17:109-114

Molyneux, R.J. and L.F. James. 1982. Loco intoxication: indolizidine alkaloids of spotted locoweed. Sci. 216:190-191.

Pulsipher, G.D., M.L. Galyean, D.M. Hallford, G.S. Smith, and D.E. Kiehl. 1994. Effects of graded levels of bentonite on serum clinical profiles, metabolic hormones, and serum swainsonine concentrations in lambs fed locoweed (Oxytropis sericea). J. Anim. Sci. 72:1561-1569.

Ralphs, M.H., D. Graham, M.L. Galyean, and L.F. James. 1997a. Creating aversions to locowed in naive and familiar cattle. $J$. Range Manage. 50:361-366.

Ralphs, M.H., D. Graham, M.L. Galyean, and L.F. James. 1997b. Influence of overwintering feed regimen on consumption of locoweed by steers. J. Range Manage. 50:250-252.

Ralphs, M.H., D.Graham, R.J. Molyneux, and L.F. James. 1993. Seasonal grazing of locoweeds by cattle in northeastern New Mexico. J. Range Manage. 46:416-420.

Ralphs, M.H., G. Greathouse, A.P. Knight and L.F. James. 2001. Cattle preference for lambert locoweed over white locoweed. J. Range Manage. 54:265-268.

Richards, J.B., D.M. Hallford, and G.C. Duff. 1999. Serum luteinizing hormone, testosterone, and thyroxine and growth responses of ram lambs fed locoweed (Oxytropis sericea) and treated with vitamin E/selenium. Theriogenology 52:1055-1066.

Stegelmeier, B.L., L.F. James, K.E. Panter, and R.J. Molyneux. 1995. Serum swainsonine concentration and $\alpha$-mannosidase activity in cattle and sheep ingesting Oxytropis sericea and Astragalus lentiginosus. Amer. J. Vet. Res. 56:149-154.

Stegelmeier, B.L., L.F. James, K.E. Panter, M.H. Ralphs, D.R. Gardner, R.J. Molyneux, and J.A. Pfister. 1999. The pathogenesis and toxicokinetics of locoweed poisoning in livestock. J. Natural Toxins $8: 35-45$. 